\title{
Innovation in Schumpeterian-type firms: Knowledge collaboration or knowledge spillover?
}

Article

Accepted Version

Belitski, M. (2019) Innovation in Schumpeterian-type firms: Knowledge collaboration or knowledge spillover? Foundations and Trends in Entrepreneurship, 15 (3-4). pp. 368-390. ISSN 1551-3114 doi: https://doi.org/10.1561/0300000085-2 Available at https://centaur.reading.ac.uk/88600/

It is advisable to refer to the publisher's version if you intend to cite from the work. See Guidance on citing.

To link to this article DOI: http://dx.doi.org/10.1561/0300000085-2

Publisher: Now

All outputs in CentAUR are protected by Intellectual Property Rights law, including copyright law. Copyright and IPR is retained by the creators or other copyright holders. Terms and conditions for use of this material are defined in the End User Agreement.

www.reading.ac.uk/centaur 
Central Archive at the University of Reading

Reading's research outputs online 


\title{
Innovation in Schumpeterian-type Firms: Knowledge Collaboration or Knowledge Spillover?
}

\author{
Maksim Belitski \\ Henley Business School, University of Reading \\ Whiteknights campus, Reading, RG6 6UD, UK \\ Email: m.belitski@ reading.ac.uk \\ Orcid ID: 0000-0002-9895-0105
}

\begin{abstract}
This study focuses on the impact of knowledge collaboration and knowledge spillovers on the innovative performance of Schumpeterian-type firms. Building on the innovation and entrepreneurship literatures, we first examine the innovation strategies used by highlyinnovative firms, which can involve knowledge spillovers, knowledge collaborations or both. Secondly, we demonstrate how and why the relationship between knowledge flows and innovative performance changes with geographical proximity between knowledge-source and knowledge-recipient firms and across industries.

External collaboration may bestow a significant advantage for innovation, such as helping to leverage the lack of knowledge and technology and teaching skills, but at a cost the involuntary knowledge outflows to external partners. Our results have relevant implications for the academic community, national and European policy-makers, and managers in highlyinnovative firms who may want to rethink their innovation strategy.
\end{abstract}

\section{Introduction}

Innovation is the most important factor affecting firm performance and survival (Cassiman and Veugelers, 2006; Chesbrough, 2003, 2006; Nieto and Santamaria, 2007; Audretsch, 2007). Empirical evidence suggests that Schumpeterian-type firms (Schumpeter, 1934) survive longer than their less-innovative counterparts, such as Kirznerian-type firms (Kirzner, 1999; Colombelli et al 2016). Schumpeterian firms are innovation-driven and engage in knowledge collaboration with external partners whilst also investing in research and development to disrupt the market equilibrium by introducing new ideas, products and services.

Firms can be very different in terms of their growth ambition, innovation and knowledge collaboration (Autio et al., 2014; Laursen and Salter, 2014) and their role in the national economy (Acs et al., 2014). Nonetheless, some firms continue to rely on formal and informal research partnerships (Hagedoorn et al 2000), knowledge sourcing (Frenz and Ietto-Gillies, 2009; Baum et al. 2000; Driffield et al., 2014) and the knowledge spillover of entrepreneurship (Audretsch et al. 2006) as the main inputs in their knowledge production function. These are rare species which appropriate the Schumpeterian view of entrepreneurship (Schumpeter 1934; Malerba and Orsenigo, 1996; Mthanti and Ojah, 2017).

Entrepreneurship is commonly estimated using the self-employment rate, new business start-ups, rate of new business ownership or other measures of entrepreneurial activity (Gartner, 1990; Alvarez and Barney 2007; Acs et al. 2008; Zahra and Wright, 2011; Cumming et al., 2014). However, Colombelli's et al. (2016) recent work argues that the above indicators do not accurately reflect Schumpeterian-type firms. Their framework and empirical analysis demonstrates that survival rates are higher when start-ups engage successfully in both product innovation and process innovation, which places innovation activity at the forefront of Schumpeterian-type firms. Interest in their high performance has sparked debate among academics, practitioners and policy-makers over where their knowledge comes from, and in 
particular the role that external knowledge sourcing (knowledge collaboration) and knowledge spillovers play in their innovative performance.

Highly-innovative start-ups and scale-ups may become a role model for other start-ups in their pursuit of innovation and engagement with a variety of knowledge providers across different institutional, industry, cultural and geographical dimensions. Currently very little is known about the benefits and risks of knowledge collaboration with external partners and how Schumpeterian-type firms leverage those risks to achieve higher performance and survival rates.

The open innovation and entrepreneurship literature calls for more evidence of company innovation strategies which destroy the pre-existing state of equilibrium (Schumpeterian-type firms), rather than pursue the equilibrative role of markets and the continuous exploitation of knowledge (Kirznerian-type firms).

In this study, we apply an entrepreneurship perspective to innovation and explain the role of knowledge collaboration/spillover in innovative performance within Schumpeterian firms. The questions to be discussed include how collaboration on knowledge across different proximities (Boschma, 2005) and external collaborators (Autio et al, 2014; Beers and Zand, 2014) changes a firm's innovative performance, and the extent to which knowledge collaborations and knowledge spillovers facilitate or impede innovation.

The remainder of the paper is as follows. Section 2 describes two mechanisms used to access external knowledge: knowledge collaboration and knowledge spillovers. Section 3 distinguishes between reverse spillovers and knowledge spillovers while collaborating on knowledge. Sections 4 applies the concept of knowledge collaboration for innovation to various industries and geographical proximities. Finally, section 5 concludes with a discussion on theoretical developments and implications.

\section{Innovation strategy and access to knowledge}

There are two main innovation strategies used to access external knowledge: knowledge spillover and external knowledge sourcing (Love et al., 2014). Both of these approaches grant access to inter-organisational knowledge (Faems et al., 2005), facilitate innovation and research (Beck and Schenker-Wicki, 2014), and contribute to the firm's knowledge production function (Roper et al., 2017).

As the open innovation literature suggested, firms should make greater strategic use of external knowledge (Chesbrough, 2003, 2006; Chesbrough et al., 2006). The benefits of knowledge collaboration have been demonstrated in a number of empirical studies that support these models (Fleming and Sorenson, 2004; Laursen and Salter, 2006; Garriga et al., 2013). Although the benefits have been widely acknowledged in the literature (Cassiman and Veugelers, 2006), the mechanisms and risks of such collaboration remain unknown (Ahuja, 2000; Baum et al., 2000; Belderbos et al., 2004).

The operationalization of external knowledge via direct knowledge collaboration and knowledge spillovers by a firm demonstrates the extent to which a firm is able to leverage its lack of internal knowledge and technology, learn skills and develop competences (Cohen and Levinthal, 1989). Access to external knowledge per se contributes to the firm's competitive advantage and facilitates further knowledge spillover of entrepreneurship (Audretsch and Lehmann, 2005; Audretsch, 2007).

\subsection{Knowledge spillovers and innovation}

We need to distinguish between knowledge transfer for collaboration and knowledge flows where there is financial compensation (knowledge collaboration) and knowledge externalities (knowledge spillover), where there is no financial compensation for the 
knowledge received. We use 'knowledge spillover' to refer to the firm benefitting from the knowledge transfer without financially compensating the knowledge source firm.

The role of knowledge spillovers is important in explaining changes in innovation (Griliches, 1979) and in particular for highly-innovative start-ups (Colombelli et al., 2016). Knowledge spillovers arise because of the imperfect appropriability of ideas (Griliches, 1991) with benefits accruing not only to the innovator, but 'spilling over' to other firms within the same region, country or industry (Jaffe et al. 1993). Knowledge spillover enriches the pool of ideas upon which subsequent innovations can be based.

The impact of spillovers on innovation performance varies across different collaborative partners (e.g. universities, suppliers, consultants, customers, competitors, enterprise groups and local and national governments) (Cassiman and Veugelers, 2006; Köhler et al. 2012; Cappelli et al. 2014) as well as geographical proximities (Jaffe et al., 1993; Audretsch and Feldman, 1996; Boschma, 2005; Balland et al., 2015). The recent open innovation literature argues that knowledge spillovers are likely to be larger for firms, which collaborate with governments, suppliers and customers (De Massis et al., 2018). Partnering with different stakeholders brings a variety of ideas and an important diversity of knowledge inputs (Lahiri, 2010; Battke et al., 2016).

The geography of innovation literature has also debated whether geographical proximity can affect knowledge spillovers, alongside other proximities such as cultural, institutional and cognitive proximity between a source and a recipient of knowledge (Boschma, 2005; Crescenzi et al. 2016) and in relation to new firm formation (Iammarino and McCann, 2006). Recent studies have followed this up with the existence of regional knowledge production modes and the role that the knowledge spillover framework plays in innovation and the recombination of knowledge, and specifically in Schumpeterian-type firms (Colombelli and Quatraro, 2018).

Studies which connect knowledge spillover to innovation performance across cognitive, cultural and geographical proximities are limited (Nooteboom et al. 2007; Schamberger et al. 2013). Most studies relate to R\&D and innovation system openness (Berchicci, 2013) and diversity of collaboration partners (Phelps, 2010).

In addition, a firm's size may become an important boundary condition affecting its ability to receive knowledge spillover and fully use available external knowledge (Bughin and Jacques, 1994; Rogers, 2004). Although small- and medium-sized firms lack absorptive capacity, knowledge spillover often remains a unique source of external knowledge (Kelley and Helper, 1999).

\subsection{External knowledge flows and innovation}

Our use of 'knowledge collaboration' and 'knowledge flows' refers to the firm benefitting from the knowledge transfer with financial compensation to the knowledge source firm from the knowledge recipient firm.

Schumpeterian-type firms collaborate with a variety of external partners and across different geographical proximities and industries (Lahiri, 2010). An increase in the intensity of collaboration between a firm and its external partners means learning skills, which leads to greater trust and a reduction in transaction costs. This may have a positive impact on product and process innovation performance, because firms become more efficient overtime via learning-by-doing. Knowledge partners improve their coordination and management to leverage negative externalities related to the transaction costs of collaboration, market uncertainty and legal knowledge protection (Nieto and Santamaria, 2007).

Knowledge collaboration increases the expectation between the knowledge source firm and the knowledge recipient firm and facilitates broader inter-disciplinary and inter-field synergies (Nooteboom et al., 2007; Beers and Zand, 2014). A wider and more diverse knowledge intake from different knowledge sources increases the likelihood of innovation, 
both radical and incremental (Chesbrough, 2003, 2006). It enables firms to develop new associations and linkages in knowledge (Cohen and Levinthal, 1989), increasing the firm's absorptive capacity and pushing the knowledge boundaries even further (Zahra and George 2002).

To be able to adopt, adapt, modify and implement external knowledge, a constant investment in the absorptive capacity of a firm is required (Zahra and George, 2002). This implies that firms themselves must have diverse experience and knowledge to develop and absorb external knowledge flows across different functional areas.

On the one hand, one may observe a positive relationship between knowledge collaboration with different partners and innovation performance, stemming from learning innovation skills and opportunities associated with the application of diverse knowledge to new markets. On the other hand, one may observe a negative relationship between knowledge collaboration with different partners (Astebro and Yong 2016) for the following reasons. First, the functional set of knowledge becomes more diverse as more partners enter into collaboration, and it becomes difficult to compare the different types of knowledge and find combinations of knowledge which allow them to be applied them strategically. Second, drawing inferences and developing new products and processes from a variety of new knowledge sources is harder, in particular when managers lack skills and a background of multi-disciplinary orientation. Third, a leakage of sensitive knowledge is possible. This is also known as reverse knowledge spillover or an involuntary knowledge outflow, due to the inability or lack of ability to appropriate the value created in collaboration.

While the variety of knowledge received from different collaborative partners contributes to a firm's knowledge function, it may generate involuntary knowledge outflows (Cassiman and Veugelers, 2006; Love et al. 2014). This leads to additional transaction and management costs, and discourages firms from collaborating (Beers and Zand, 2014).

\section{External knowledge collaboration and reverse spillovers}

Reverse spillovers associated with involuntary knowledge outflows while collaborating with external partners are a particular thereat to firms. Involuntary knowledge outflows challenge the benefits of collaboration (Chesbrough, 2003, 2006) and may restrain firms from engaging in knowledge collaboration with external partners. As the risk of involuntary knowledge outflows increases, the extent of knowledge collaboration is likely to decline. In this case, knowledge spillovers will remain the 'safest' form of external knowledge sourcing (Audretsch, 2007; Audretsch and Keilbach, 2007).

Reverse spillovers are generated through a variety of mechanisms - the mobility of workers (moving to competitors and collaborators), the exchange of information at technical conferences and in open access publications, as well as reengineering and the use of knowledge available to third parties. Unlike knowledge spillovers, reverse spillovers are difficult to measure and control as the flow of knowledge and benefits which accrue to the knowledge recipient are unknown and dispersed over time. The term 'reverse spillovers' is applied to the knowledge source firm only. The major difference between these two spillovers is that reverse spillovers may be the result of infringement of knowledge by the knowledge recipient firm, which has not yet been protected (patented, copyrighted) by the knowledge source firm.

Laursen and Salter (2006) focus on the breadth of knowledge collaboration across a range of different partners, including suppliers, customers and universities, in order to capture the firm's openness to external knowledge. It is debatable whether collaboration with more functionally-diverse partners minimizes the chances of reverse spillovers, as the knowledge flows might be less specialised. On the contrary, collaboration with multiple partners makes it more complicated to track the knowledge leakage. This is because each channel of 
collaboration involves interactions with different communities of practice which may have opposing sets of institutional norms, habits and rules. Firms choosing to work with external partners need to develop (often costly) organizational practices that are suited to the domain in which they research and which will be able to protect them from reverse spillovers.

Knowledge spillovers in this instance can be seen as a form of 'informal' openness, typically involving knowledge flows made available by the knowledge source without binding contract requirements, legal agreements and procedures, or limitations on the use of products. For example, knowledge recipients can acquire knowledge by buying products and services from knowledge-intense firms in the national and international markets (Capello, 2009). These products could be later disassembled and reverse-engineered, sourced and combined with different products or services (Lieberman and Montgomery, 1998).

External knowledge collaboration as a form of 'formal' openness is more likely to be associated with legal conditions and a focus on the breadth and depth of knowledge flows between partners and the firm's formal collaboration relationships for innovation. Although the setting up of a formal knowledge collaboration requires a stronger commitment from managers, this type of cooperation aims to protect the knowledge-source firm and provide knowledge-recipient firms with access to more sensitive knowledge and in-depth collaboration and serves as a complementary resource to specific knowledge-production needs.

For example, a collaboration between partners on knowledge may require access to advanced knowledge and prototyping ideas via communication with a focal firm's leaders and technical experts, enterprise visits, apprenticeships, scholarships and the exchange of specialists (Almeida and Kogut, 1999).

'Headhunting' workers from rivals may become of another form of reverse spillover. Knowledge source firms are aware of this channel and aim to legally protect sensitive knowledge via bounding contracts with a firm's leaders and their technical experts. Headhunting workers is a specific knowledge transfer channel where there is no direct financial compensation between the knowledge-recipient firm and knowledge-source firm; it is neither knowledge externality nor knowledge collaboration. This form of knowledge transfer is used in industries where knowledge is not readily available to use, in particular in highly-complex industries where reverse engineering is limited or impossible without specific knowledge transfer to the knowledge recipient firm.

\section{Knowledge collaboration and knowledge spillovers across industries and geographical proximities}

Different sectors are unlikely to be equally affected by knowledge inflows and outflows. There are many reasons for this, including reverse spillovers and the nature of knowledge. Reverse spillovers are most likely to occur in firms and industries where collaborators will perceive the widest scope of knowledge available to source, in addition to low or no penalties on knowledge infringement. Industries that have invested heavily in R\&D are likely to see the most benefits from knowledge collaboration, including involuntary knowledge outflows (Cassiman and Veugelers, 2002, 2006). Firms in industries rich in knowledge have a high absorptive capacity (Cohen and Levinthal, 1989), a high concentration of knowledge workers, and are becoming more attractive as a source new knowledge to firms in complementary industries.

Reverse spillovers are associated with knowledge collaboration in sectors where knowledge is tacit and still undefined, e.g. education and services, research and development, experimental studies and knowledge processing. These sectors will be more attractive to external knowledge sourcing due to the nature of knowledge which is neither publicly available nor perfectly protected (Zucker et al. 1998). 
Industries rich in knowledge may experience higher reverse spillovers, but not necessarily higher knowledge spillovers. The rationale behind this is that knowledge source firms in knowledge-intense industries are less likely to enforce appropriability mechanisms and protect their knowledge. Firstly protection mechanisms, including patents, registration of designs, secrecy, package complexity and others, are negatively associated with openness to collaboration (Laursen and Salter, 2014). Secondly, in the prototype and demo stages of product development, ideas are not fully protected as is the usual case in knowledge-intensive business services, high-tech manufacturing, ICT and the creative sector.

Industries where knowledge has not yet been explored and exploited limits its applicability elsewhere, e.g. this limits the knowledge spillover to other industries where recombination or further developments could be made. The knowledge may not yet be ready to be implemented and commercialised. For example, knowledge spillovers are likely to take places in firms and industries where the attractiveness of the product is high, knowledge is openly shared (conferences, publications, collaboration) and the product has already been introduced or is close to market introduction.

Although the knowledge transfer may not take place as the knowledge recipient firm may avoid paying for the knowledge, both parties 'test the waters' by exploiting market opportunities, along with visualising and modifying the characteristics of the product. This brings additional benefits to the prospective knowledge source and recipient firm. The phenomenon of knowledge collaboration under high reverse spillovers has received special attention in the management and international literatures (Driffield et al., 2014).

While the relevance of knowledge collaboration across different industries has been broadly cited (Cassiman and Veugelers, 2002, Laursen and Salter, 2014), another strand of research emphasises the role of geographical proximities in connecting knowledge externalities and innovative performance (Boschma, 2005). The research on various geographical dimensions of knowledge collaboration has mixed evidence (Audretsch and Feldman, 1996; Crescenzi et al., 2016; Audretsch and Belitski, 2017). While some studies claim that having local and national partners is more important and is associated with higher levels of innovative performance, other studies argue that maintaining predominantly local and national partners as sources of knowledge leads to a "lock-in effect" (Nooteboom, 2000; Boschma, 2005).

Consistent with the above line of reasoning, knowledge spillovers and knowledge collaborations across different geographical proximities are likely to affect innovation in firms in a similar way.

One may expect that knowledge spillovers and knowledge collaborations with regional and national partners for innovation are likely to be important for the following reasons. First, national boundaries are where market knowledge is relevant for firms that target local and national markets, in particular at the beginning of their lifecycle, before going international. Secondly, competition is less intense in regional and national markets and protection of intellectual property rights could be better enforced, as opposed to the international institutional environment with many different intellectual property standards and regulations along with intense competition. Third, regional and national partners offer customised services and provide firms with information and knowledge valid for national market which can be implemented readily. This will lower the firm's R\&D investment costs.

At the same time, knowledge spillovers and knowledge collaborations with international partners are also important for innovation performance. Firstly, the knowledge received through knowledge spillovers from international collaboration is tailored to allow businesses to enter different geographical markets and more effectively respond to the demands of international customer across different geographical proximities. Secondly, innovative firms are likely to pay more attention to heterogeneous knowledge sources due to the uniqueness and 
originality of knowledge available across different types of partners internationally. Thirdly, the benefits of knowledge spillover internationalization outweigh the costs (Lahiri, 2010).

Knowledge spillovers and knowledge collaborations with partners across both near and distant geographical dimensions are important for firm innovation. Boschma and Frenken (2010) offers a "proximity paradox", which means that being too far and too close can reduce the scope of learning from a partner.

\section{Discussion and conclusion}

This paper has discussed the following theoretical developments. Firstly, this study demonstrated that the relationship between knowledge collaboration and innovation is likely to be non-linear due to the existence of both knowledge benefits from collaboration and reverse spillovers. The non-linear relationship also emerges due to geographical, cognitive and institutional proximities related to the appropriability of knowledge and the costs of knowledge exploitation with partners. Secondly, this study provided further insights into the positive and linear relationship between knowledge spillovers and innovation, positioning knowledge spillovers as an essential conduit of innovation in Schumpeterian-type firms.

The theorizing and derived propositions stretch the knowledge boundaries of the entrepreneurial perspective to innovation as well as the interplay between knowledge collaboration, knowledge spillovers and innovation. This study discussed several of the implications for the entrepreneurship and open innovation fields of literature.

Firstly, the current literature on open innovation in entrepreneurial firms includes mixed and often conflicting views on the relationship between knowledge flow and firm innovation, often capturing the 'left-over' positive effect of knowledge collaboration (von Hippel, 2005). This paper argues that openness and knowledge collaboration serves as a conduit for innovation in Schumpeterian firms, but at the cost of involuntary knowledge outflows, transaction costs and institutional risks. Knowledge collaboration is shaped by the adjustment of knowledge flows to geographical, institutional and cognitive optimums.

Secondly, knowledge collaboration with external partners has a hidden negative effect on innovation performance which is related to appropriability issues, involuntary knowledge outflows and reverse spillovers (Driffield et al. 2014). Although knowledge collaboration speeds up the process of discovery of new products and services, legal issues and ownership on innovation emerge as an important boundary condition for innovation protection (Bessen and Maskin, 2009). The recent open innovation literature explains how differences in institutional environments (Acs et al., 2014; Autio et al. 2014) may change the appropriability regimes and limit the degree of openness (Chesbrough and Teece, 1996; Chesbrough, 2006). This is an important issue because the existence of knowledge appropriability may give managers the confidence to engage more widely in external collaboration.

Thirdly, Schumpeterian firms are likely to benefit more from the knowledge spillover of entrepreneurship and from knowledge collaboration. For Schumpeterian-type firms, which are usually small in size, knowledge spillovers emerge as an efficient channel of knowledge transfer from more experienced but less flexible incumbent firms. The innovation strategy with another Schumpeterian-type firm may be more cautious, with an emphasis on knowledge protection and creating and capturing value from collaboration.

Future research may want to analyse the non-linearity of the relationship between knowledge collaboration / spillovers and innovative performance. While the relationship between the knowledge collaboration and innovation is likely to be non-linear and in particular across different geographical, cognitive and institutional proximities; the relationship between knowledge spillovers and innovative performance is likely to be positive with "the more - the better" case. The research will contribute to the discussion of Capello (2009), who argues 
knowledge spillovers might produce both positive and negative externalities on a firm's performance. Should this be the case then a firm may anticipate an optimum level of knowledge collaboration between two firms (knowledge recipient and knowledge source).

Subsequent research will focus on the relationship between innovation performance and knowledge collaboration for both the knowledge-recipient and knowledge-source firms. The benefits of knowledge collaboration can be measured as a difference between the potential benefits from knowledge flows and its cost. The special case is internationalization of Schumpeterian-type firms. On the one hand, their internationalization strategies may need to be adjusted to protect innovation, and in particular in collaboration with the overseas partners outside and across different intellectual property protection regimes. On the other hand, they need to be careful not to get locked up within local knowledge base with the highest protection possible. The excessive reliance on either close or distant geographically proximity of the Schumpeterian-type firms should be further researched and suggestions made in regard to knowledge flows and the ability of Schumpeterian firms to transform knowledge into innovation across close and distant proximities.

In addition, a study on entrepreneur attitudes to openness and knowledge appropriability will provide further insights on the role that entrepreneurs play in this relationship. Firstly, entrepreneur attitudes either increase or decrease the linear effect of knowledge spillovers on innovation; secondly, they may shift (to the left or to the right) the non-linear relationship between the extent of collaboration and innovative performance. This suggests that future research needs to unpack the underlying pillars which influence a firm's innovation strategy on openness may such as the firm type (Schumpeterian or Kirznerian entrepreneur), industry knowledge, geographical and other proximities (Balland et al., 2015), diversity in collaboration partners (Beers and Zand, 2014) and more. Schumpeterian-type firms as well as many other small- and medium-sized businesses lack resources and competences in their early stages but require novel ideas and knowledge exchange. The question for the further research could be: to what extent entrepreneurs should engage in external knowledge collaboration with different partners across a variety of industries and geographical proximities, or rely on knowledge spillover and internal absorptive capacity, or both?

\section{References}

Ács, Z. J., Autio, E. and L. Szerb (2014), 'National systems of entrepreneurship: Measurement issues and policy implications'. Research Policy 43(3), 476-494.

Ahuja, G. (2000), 'Collaboration networks, structural holes, and innovation: A longitudinal study.' Administrative science quarterly, 45(3), 425-455.

Almeida, P. and B Kogut. (1999), 'Localization of knowledge and the mobility of engineers in regional networks.' Management science, 45(7), 905-917.

Åstebro, T. and K. Yong (2016), 'Invention quality and entrepreneurial earnings: the role of prior employment variety'. Entrepreneurship Theory and Practice 40(2), 381-400.

Audretsch, D.B., and M.P. Feldman (1996). 'R\&D spillovers and the geography of innovation and production', The American economic review, 86(3), 630-640.

Audretsch, D. B. and E. Lehmann (2005), 'Does the knowledge spillover theory of entrepreneurship hold for regions?' Research Policy, 34(8), 1191-1202.

Audretsch, D. B. (2007), 'The entrepreneurial society'. Oxford University Press.

Audretsch, D. B. and M. Keilbach (2007). 'The theory of knowledge spillover entrepreneurship'. Journal of Management Studies 44(7), 1242-1254.

Audretsch, D. B. and M. Belitski (2013), 'The missing pillar: The creativity theory of knowledge spillover entrepreneurship'. Small Business Economics 41(4), 819-836. 
Audretsch, D.B. and Belitski, M. (2017). Entrepreneurial ecosystems in cities: establishing the framework conditions. The Journal of Technology Transfer, 42(5), 1030-1051.

Autio, E., Kenney, M., Mustar, P., Siegel, D. and M. Wright (2014), 'Entrepreneurial innovation: The importance of context', Research Policy, 43(7), 1097-1108.

Balland, P-A, R. Boschma and K. Frenken (2015), 'Proximity and innovation: From statics to dynamics'. Regional Studies, 49(6), 907-920.

Baum, J.A.C., Calabrese, T. and B.S. Silverman (2000) 'Don't Go It Alone: Alliance Network Composition and Startups' Performance in Canadian Biotechnology,' Strategic Management Journal, 21(3), 267-294.

Battke, B., T. S. Schmidt, S. Stollenwerk and V.H. Hoffmann (2016), Internal or external spillovers - Which kind of knowledge is more likely to flow within or across technologies'. Research policy 45(1), 27-41.

Beck, M. and A. Schenker-Wicki (2014), Cooperating with external partners: the importance of diversity for innovation performance.' Eur. J. Int. Manag, 8, 548-569.

Beers, C. and F. Zand (2014), 'R\&D cooperation, partner diversity, and innovation performance: an empirical analysis', Journal of Product Innovation Management, 31(2), 292312.

Belderbos, R., M. Carree and B. Lokshin (2004), 'Cooperative R\&D and firm performance', Research policy, 33(10), 1477-1492.

Berchicci, L. (2013), 'Towards an open R\&D system: Internal R\&D investment, external knowledge acquisition and innovative performance'. Research Policy 42(1), 117-127.

Boschma, R. (2005), 'Proximity and innovation: a critical assessment'. Regional studies 39(1), 61-74.

Boschma, R. and K. Frenken (2010), 'The spatial evolution of innovation networks. A proximity perspective'. The handbook of evolutionary economic geography, 120-135.

Bughin, J. and J.M. Jacques (1994), Managerial efficiency and the Schumpeterian link between size, market structure and innovation revisited. Research Policy 23(6), 653-659.

Cappelli, R., D. Czarnitzki and K. Kraft (2014), 'Sources of spillovers for imitation and innovation'. Research Policy 43, 115-120.

Cohen, W. M. and D.A. Levinthal (1989), 'Innovation and learning: the two faces of R\&D', The Economic Journal, 99(3), 569-596.

Capello, R (2009), 'Spatial spillovers and regional growth: a cognitive approach', European Planning Studies, 17(5), 639-658.

Cassiman, B. and R. Veugelers (2002), 'R\&D cooperation and spillovers: some empirical evidence from Belgium'. American Economic Review, 92(4), 1169-1184.

Cassiman, B. and R. Veugelers (2006), 'In search of complementarity in innovation strategy: internal R\&D and external knowledge acquisition'. Management Science 52, 68-82.

Chesbrough, H. W. and D.J. Teece (1996), 'Organizing for innovation'. Harvard business review 74(1), 65-73.

Chesbrough, H. (2003), 'Open Innovation'. Harvard University Press: Cambridge, MA. Chesbrough, H. (2006), 'Open Innovation: The New Imperative for Creating and Profiting from Technology'. Harvard Business Press: Boston, MA.

Chesbrough, H., W. Vanhaverbeke and J. West, J. (2006). 'Open Innovation: Researching a New Paradigm'. Oxford University Press: Oxford.

Colombelli, A., Krafft, J. and M. Vivarelli, M. (2016), 'To be born is not enough: The key role of innovative startups'. Small Business Economics 47, 277-291.

Colombelli, A. and F. Quatraro (2018). 'New firm formation and regional knowledge production modes: Italian evidence'. Research Policy 47(1), 139-157.

Crescenzi, R., M. Nathan and A. Rodríguez-Pose (2016), 'Do inventors talk to strangers? On proximity and collaborative knowledge creation'. Research Policy 45(1), 177-194. 
Cumming, D., S. Johan and M. Zhang (2014), 'The economic impact of entrepreneurship: Comparing international datasets'. Corporate Governance: An International Review 22(2), 162-178.

De Massis, A., D. Audretsch, L. Uhlaner, and N. Kammerlander (2018), 'Innovation with limited resources: Management lessons from the German Mittelstand'. Journal of Product Innovation Management, 35(1), 125-146.

Driffield, N., J.H. Love, and Y. Yang. (2014), 'Technology sourcing and reverse productivity spillovers in the multinational enterprise: global or regional phenomenon?' British journal of management 25, S1.

Faems, D., B. Van Looy and K. Debackere (2005), 'Interorganizational collaboration and innovation: Toward a portfolio approach,' Journal of product innovation management, 22(3), 238-250.

Frenz, M., and G. Ietto-Gillies, (2009), 'The impact on innovation performance of different sources of knowledge: Evidence from the UK Community Innovation Survey', Research Policy 38(7), 1125-1135.

Fleming, L. and O. Sorenson (2004), 'Science as a map in technological search,' Strategic Management Journal 25, 909-928.

Garriga, H., G. Von Krogh and S. Spaeth (2013), 'How constraints and knowledge impact open innovation'. Strategic Management Journal 34(9), 1134-1144.

Griliches, Z. (1979), 'Issues in assessing the contribution of research and development to productivity growth'. The bell journal of economics, 92-116.

Griliches, Z (1991), 'The search for R\&D spillovers'. National Bureau of Economic Research, No. w3768.

Hagedoorn, J., A. N. Link and N.S. Vonortas (2000). 'Research partnerships'. Research policy 29(4-5), 567-586.

Iammarino, S. and P. McCann (2006), 'The structure and evolution of industrial clusters: Transactions, technology and knowledge spillovers', Research policy 35(7), 1018-1036.

Jaffe, A. B., M. Trajtenberg and R. Henderson (1993), 'Geographic localization of knowledge spillovers as evidenced by patent citations'. Quarterly Journal of Economics 63(3), 577-598.

Kelley, M. R. and S. Helper (1999), Firm size and capabilities, regional agglomeration, and the adoption of new technology'. Economics of Innovation and New technology 8, 79-103.

Kirzner, I. M. (1999), 'Creativity and/or alertness: A reconsideration of the Schumpeterian entrepreneur'. The Review of Austrian Economics 11(1-2), 5-17.

Köhler, C., W. Sofka and C. Grimpe (2012), 'Selective search, sectoral patterns, and the impact on product innovation performance'. Research Policy 41(8), 1344-1356.

Lahiri, N. (2010). 'Geographic distribution of R\&D activity: how does it affect innovation quality?' Academy of Management Journal 53(5), 1194-1209.

Laursen, K. and A.J Salter (2006), Open for innovation: the role of openness in explaining innovative performance among UK manufacturing firms. Strategic Management Journal 27, 131-150.

Laursen, K. and A.J Salter (2014), 'The paradox of openness: Appropriability, external search and collaboration', Research Policy, 43(5), 867-878.

Lieberman, M.B. and D.B. Montgomery (1998), 'First-mover (dis)advantages: retrospective and link with resource-based view.' Strategic Management Journal 19, 1111-1125.

Love, J.H., S. Roper and P. Vahter (2014), 'Learning from openness: The dynamics of breadth in external innovation linkages'. Strategic management journal 35, 1703-1716.

Malerba, F. and L. Orsenigo (1996), Schumpeterian patterns of innovation are technologyspecific. Research policy 25(3), 451-478.

Mthanti, T. and K. Ojah, K. (2017), 'Entrepreneurial orientation (EO): Measurement and policy implications of entrepreneurship at the macroeconomic level'. Research Policy 46(4), 724-739. 
Nieto, M.J. and L. Santamaría (2007), 'The importance of diverse collaborative networks for the novelty of product innovation.' Technovation 27, 367-377.

Nooteboom, B. (2000), 'Learning by interaction: absorptive capacity, cognitive distance and governance'. Journal of management and governance 4(1-2), 69-92.

Nooteboom, B., W. Van Haverbeke, G. Duysters, V. Gilsing and A. Van den Oord (2007), 'Optimal cognitive distance and absorptive capacity'. Research policy 36(7), 1016-1034

Phelps, C. C. (2010), 'A longitudinal study of the influence of alliance network structure and composition on firm exploratory innovation'. Academy of management journal 53(4), 890-913. Rogers, M. (2004), 'Networks, Firm Size, and Innovation,' Small Business Economics, 22(2), 141-153.

Roper, S., J. Love and K. Bonner (2017), 'Firms' knowledge search and local knowledge externalities in innovation performance', Research Policy, 46, 43-56.

Schamberger, D. K., N. J. Cleven and M. Brettel (2013), 'Performance effects of exploratory and exploitative innovation strategies and the moderating role of external innovation partners'. Industry and Innovation, 20(4), 336-356.

Schumpeter, J. A. (1934). 'The theory of economic development'. Cambridge, Mass.: Harvard University Press.

von Hippel, E. (2005), 'Democratizing Innovation'. MIT Press: Cambridge, MA.

Zahra, S. A. and G. George (2002), 'Absorptive capacity: A review, reconceptualization, and extension'. Academy of management review 27(2), 185-203.

Zahra, S. A. and M. Wright (2011), 'Entrepreneurship's next act'. The Academy of Management Perspectives 25(4), 67-83.

Zucker, L. G., M. R. Darby and M. B. Brewer (1994), 'Intellectual human capital and the birth of US biotechnology enterprises'. NBER Working Paper No. 4653. 